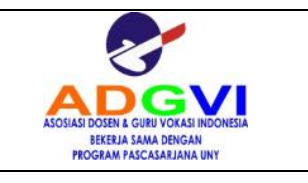

\title{
INDUSTRIAL ASSESSMENT TO TECHNICAL AND EMPLOYABILITY SKILLS STUDENTS BASED ON KKNI (IN JAKARTA REGION)
}

\author{
Rina Febriana \\ Lecturer, Faculty of Engineering, UniversitasNegeri Jakarta \\ rinafebriana@unjac.id \\ Agung Premono \\ Lecturer, Department of Mechanical Engineering, UniversitasNegeri Jakarta \\ agung-premono@unj.ac.id \\ Tuti Iriani \\ Lecturer, Faculty of Engineering, UniversitasNegeri Jakarta \\ t_iriani @yahoo.com

\begin{abstract}
This study aims to determine the industrial assessment of technical and employability skills of students. The research was conducted by using survey method in several industries as the place of the Job Training (PKL) of the students. The research technique used purposive random sampling with respondents in this research consist of 23 industry in Jakarta area. The results of the research are (1) the industrial assessment of the technical skills of the students obtained a score of 73.10 with high interpretation; (2) The industry average rating of employability of students skills is 83.10 with very high interpretation.
\end{abstract}

Keywords: technical skills, employability skills, assessment, industry 


\section{INTRODUCTION}

This research is a preliminary study to make an assessment instrument development in the field of expertise based on the Indonesian National Qualification Framework (Kerangka Kualifikasi Nasional Indonesial KKNI). As a preliminary research, this study aims to obtain information related to industry assessment of students' technical and employability skills as preliminary data to determine indicators that can be used as a reference in developing assessment instruments.

Field Work Practice (PKL) is one of the systematic and synchronized forms of empowerment between educational programs in Higher Education with skills acquisition programs obtained through work activities directly in the world of work to achieve a certain level of expertise. PKL activity is a means of proving students' competence either from technical skills aspect or students employability skill after experiencing learning process in the educational institution.

Assessment of technical skills and employability skills in line with the demands of the Indonesian National Qualifiers Framework (KKNI) which divides the learning outcomes based on the qualification level. The framework of job qualification that matches, equalizer, integrates the education and training sectors and work experience in the framework of providing job competence recognition in accordance with job positions in various sectors. The Indonesian National Qualification Framework (KKNI) consists of 9 (nine) levels of qualification, starting from qualification 1 as the lowest qualification to Qualification 9-as the highest qualification (Presiden Republik Indonesia, 2012).

According to KKNI, Diploma III Program is directed to graduates who master the ability in the field of work that is routine and who are not familiar with nature and contextual, independently in the implementation and job responsibilities, and able to carry out supervision and guidance on the basis of managerial skills possessed. Based on the above description, this research is oriented on the assessment of the industry to the technical skills and employability skills of students who are integrated with qualifications at level 5 KKNI qualification.

\section{Indonesia National Qualification Framework (KKNI)}

The Indonesian National Qualification Framework (KKNI) is a framework of job qualification that matches, equates, integrates, the education and training sectors and work experience in the framework of providing job competence recognition in accordance with job positions in various sectors.

The Indonesian National Qualification Framework (KKNI) consists of 9 (nine) levels of qualification, starting from qualification 1 as the lowest qualification to 9th qualification as the highest qualification.

Based on KKNI description of learning achievement for Diploma III which is then formulated in Decree of the Minister of National Education of Republic of Indonesia Number 232/U/2000 About Guidelines for Preparation of Higher Education Curriculum and Assessment of Learning Outcomes as follows:

"Diploma III program is directed to graduates who master the ability in the field of work that is routine and who are not familiar with the characteristics and contextual, independently in the implementation and job responsibilities, and capable of carrying out supervision and guidance On the basis of his managerial skills" (Menteri Pendidikan dan Kebudayaan Republik Indonesia, 2013).

The following table is a competency on level 5 for Diploma 3 based on KKNI.

Tabel 1. Qualification of KKNI Level - 5

\begin{tabular}{|c|c|c|}
\hline No & Areas & Description of KKNI Level 5 \\
\hline 1 & $\begin{array}{l}\text { Work } \\
\text { Skills }\end{array}$ & $\begin{array}{l}\text { Be able to complete wide-ranging work, } \\
\text { choose appropriate methods from various } \\
\text { option that have been or have not been } \\
\text { standardized by analyzing the data, and } \\
\text { able to demonstrate performance with } \\
\text { quality and quantity measured. }\end{array}$ \\
\hline 2 & $\begin{array}{l}\text { Know- } \\
\text { ledge }\end{array}$ & $\begin{array}{l}\text { Be able to complete wide-ranging work, } \\
\text { choose appropriate methods from various } \\
\text { option that have been or have not been } \\
\text { standardized by analyzing the data, and } \\
\text { able to demonstrate performance with } \\
\text { quality and quantity measured. }\end{array}$ \\
\hline 3 & $\begin{array}{l}\text { Mana- } \\
\text { gerial }\end{array}$ & $\begin{array}{l}\text { Able to manage working groups and } \\
\text { prepare comprehensive written reports. }\end{array}$ \\
\hline 4 & $\begin{array}{l}\text { Attitude/ } \\
\text { Character } \\
\text { /Personal- } \\
\text { ity }\end{array}$ & $\begin{array}{l}\text { Responsible for the work itself and can be } \\
\text { given responsibility for the achievement } \\
\text { of group work. }\end{array}$ \\
\hline
\end{tabular}




\section{Technical Skills}

Technical skills are skills in the field of work that includes knowledge and skills. Investopedia defines technical skills as a technical work skill that refers to one's talents and skills to perform a particular job or task. In addition, technical skills are also called hard skills as opposed to soft skills, namely personality, and character (Anonymous, n.d.).

If it is associated with the realm of KKNI, the technical skills are identical with the work skills and knowledge of the work field. Work skills include; Capable of completing wide-ranging work, selecting appropriate methods from a variety of pre-existing and non-standard options by analyzing data, and being able to demonstrate performance with measurable quality and quantity. While working knowledge consists of mastering the theoretical concepts of a particular field of knowledge in general, and able to formulate the solution of procedural problems.

\section{Employability Skills}

Yorke \& Knight (2006) defines employability as "a set of achievements, understandings and personal attributes that make individuals more likely to gain employment and be successful in their chosen occupations, which benefits themselves, the workforce, the community and the economy" Achievements, understandings and attributes of one who make the individual more likely to gain employment and succeed at the choice of work that benefits him, the workforce, society, and the economy.

In the employability skills research for the future report (Departement of Education Science and Training, 2002) it is mentioned that "employability skills are defined as' skills required not to gain employment, but also to progress one's potential and contribute successfully to enterprise strategic directions". Employability skills are defined as the skills required not only to gain employment but also for advancement within the company to increase one's potential and contribute to the strategic direction of the company's success.

Learning and Skills Improvement Service (2010) states that "Skills for Life and employability should be central to your preredundancy offer", skills for living and working should center on the supply of surplus.
Furthermore, it was added that "Improved literacy, numeracy, and language skills can have a positive impact on people and their employment prospects. These generic skills can help them to learn new sector-specific and workplace skills ", improving reading, counting, language skills can have a positive impact on people and their job prospects. (Learning and Skills Improvement Service, 2010). Workplace learning provides opportunities for learners to develop and apply knowledge, skills, and work attitudes and behaviors that lead to better and more productive career and job information (Morley, 2010, p. 40).

Competence in the world of work is interpreted as a personal aspect (LOMA's Competency Dictionary, 2006). These personal aspects include nature, motives, value systems, attitudes, knowledge, and skills. The research conducted by Wagiran (2008) on the urgency of graduate competency aspects needed in the industrial world shows that the important aspects of competence are: honesty, work ethic, responsibility, discipline, applying the principles of occupational safety and health, initiative and creativity. It is clear that in terms of competence and skills required, soft skills have a key role in determining the qualifications required by the industry.

This finding is in line with the study conducted by Samani (2004) who found the main competency order needed by the industry which includes: honest, discipline, responsibility, cooperation, problem-solving, and occupation. In line with that, a recent study conducted by Andreas (2007) in demonstrating that the major competencies expected by the industry include an order: honest, discipline, communication, cooperation, and mastery of the field of study (Samani, 2004).

The demand for work skills changes over time. The world of work not only demands to understand and do the job well in the field it is engaged in but also must have the competence and skills that can maintain the continuity of work with better conditions. From some of the above explanations, it can be concluded that employability skills is a set of skills that must be owned by someone in an effort to get a job or improve performance in the workplace.

If it is related to the realm of KKNI than technical skills are identical with managerial ability and knowledge of work field and 
attitude/character/personality. Managerial skills include; Able to manage the working group and prepare a comprehensive written report. While attitude/character/ personality that has an indicator: responsible for the work itself and can be given responsibility for the achievement of group work.

\section{Practice Field Work (PKL)}

Field Work Practice is one form of systematic and synchronous implementation between educational programs in Higher Education with skills acquisition program obtained through work activities directly in the world of work to achieve a certain level of expertise.

The purpose of the street vendors is one of the activities of the Students to seek work experience before entering the real world of work reflected in the National Education based on Pancasila which aims to improve intelligence, creativity, and skills in order to grow people who can build themselves and are responsible for The development of the nation and state in the achievement of an improved economy and a prosperous life. The cooperation between industry and schools in terms of prakerin has contributed a great deal to the increase in the competence of student skills (Indriaturrahmi \& Sudiyatno, 2016).

Handayani \& Wening (2016) stated how to obtain competence by students when implementing pre-kerin are: (1) active communication and good cooperation; (2) the use of bel-teach techniques that hear, see and do; (3) the use of appropriate, practical, fast and safe working methods; (4) working independently; (5) work with a genuine sense of responsibility; (6) uphold the work ethic; (7) good organizing and im-plementation in work; (8) undertake work based on trust provided by the industrial instructor (industry guides); (9) doing work that has not previously been done; (self-development); (10) applying commission that has been obtained from school.

\section{METHOD}

The Research method used in this research is survey method. Survey research is one of the research approaches that are generally used for large and multiple data collection. Survey research is a study that collects information from a sample by asking through questionnaires or interviews describing various aspects of the population (Fraenkel \& Wallen, 1990).

The purpose of survey research is to know the general description of the characteristics of the population. Survey research is used to collect information in the form of opinions from a large number of people on a particular topic or issue. The research roadmap can be seen in the following chart:

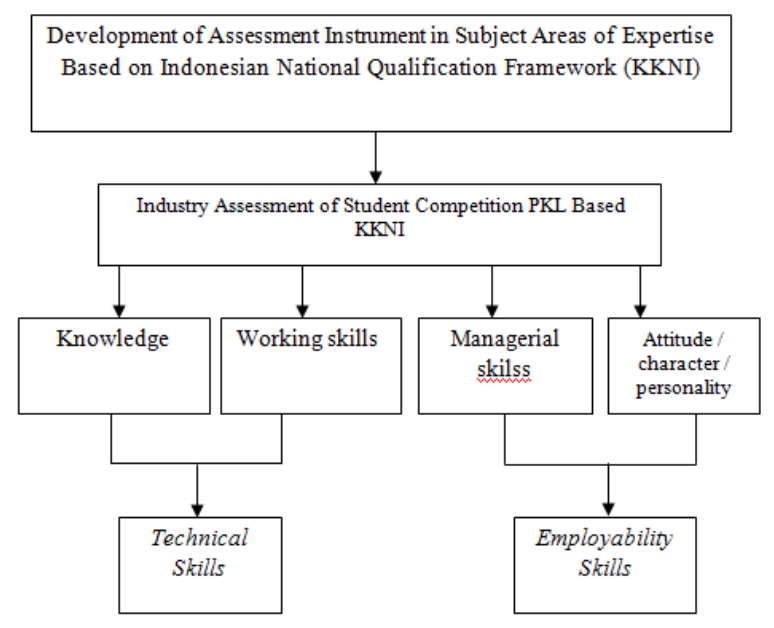

Figure 1. Research Mindset

To collect data about technical and employability skills it is necessary to compile the grid and instrument grids used in research. The research instrument is a questionnaire to assess Technical and Employability skills.

The data collection technique is done by giving technical assessment questionnaire and employability skill which contains written a statement to respondent which contains 19 point statement.

The measurement of industry assessment by the instrument in the form of a questionaire acceptance attitude. This questionnaire using Likert scale (Ridwan, 2007) as an alternative to the answer so feach respondent's statements and the grains can choose one answer that fits. Every item the answer is worth 1 (one) to 4 (four) in accordance with the level of the answer, i.e.exelent (SS), good (S), poorly (TS), not good (STS). The procedures undertaken in this study are as follows Figure 2. 
Tabel 2. The Industry Assessments of the Instruments based KKNI

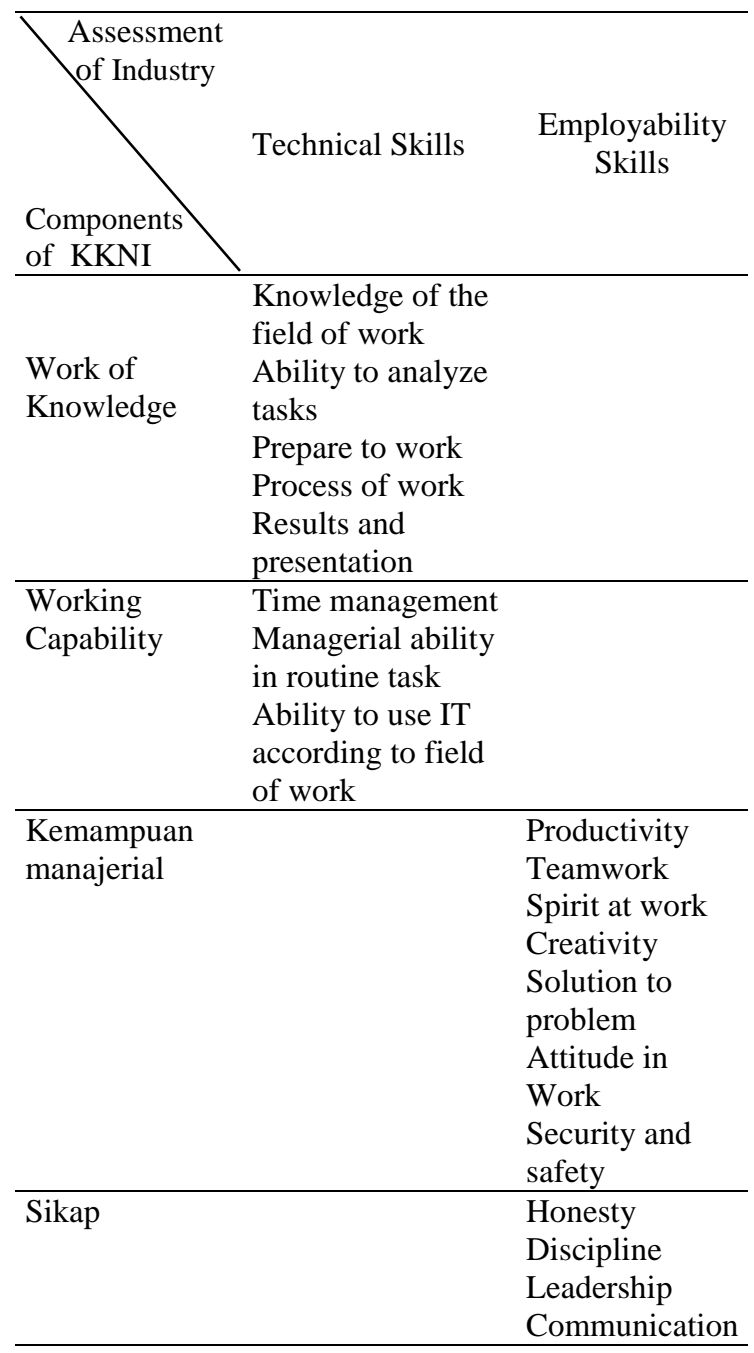

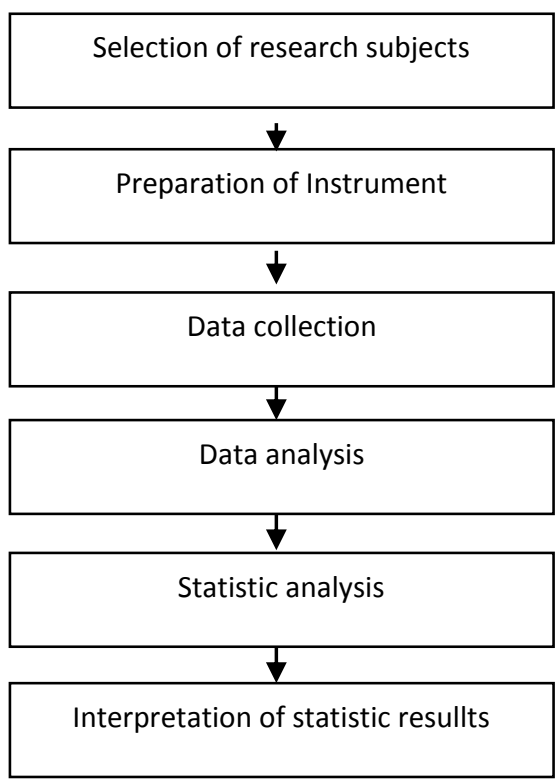

Figure 2. Research Procedure
Data analysis techniques in this study using descriptive statistics and variable trends. The tendency criteria used in this study refers to the formula developed by Azwar (2011).

Tabel 3. Trend of Variables

\begin{tabular}{ll}
\hline R Value & Interpretation \\
\hline $0.800-1,000$ & Very High \\
$0,600-0,799$ & High \\
$0,400-0,599$ & Enough \\
$0,200-0,399$ & Low \\
\hline
\end{tabular}

\section{RESULT AND DISCUSSION}

\section{Description of Industrial Data for Technical Skills Students}

Values obtained from the assessment of student technical skills instruments consisting of 2 indicators of working knowledge and ability of work can be seen in the description below the work of knowledge.

Work knowledge is the ability of a person in the realm of cognitive/knowledge of the field of work. Knowledge of work can be identified through indicators of knowledge about the field of work and the ability to analyze the task being done.

Here is an industry assessment of aspects of student work knowledge

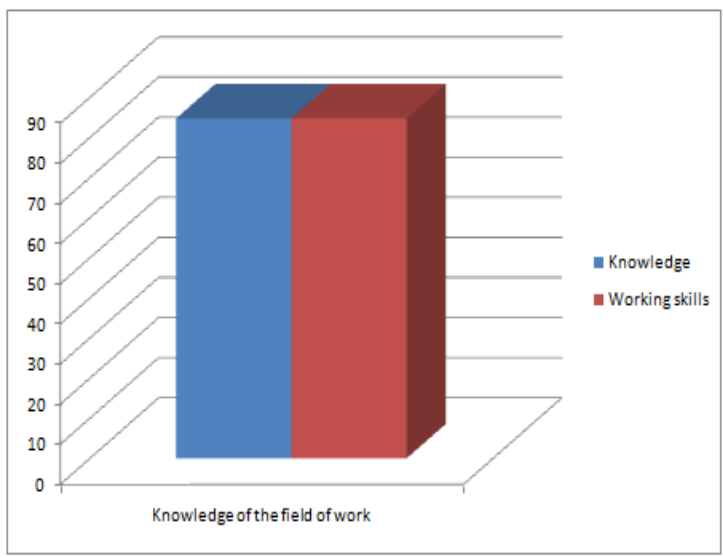

Figure 3. Values of Work Knowledge and Ability of Student Task Analysis based on Industrial Assessment

From the instrument given to 23 respondents of the industrial world to the knowledge, aspect obtained a value for the aspect of working knowledge of 84.78 and the aspect of the task analysis capability of 84.78 . The 
overall average value of the working knowledge aspect was obtained 84.78 with very high interpretation. The overall average value of the knowledge aspect of the work area is as follows:

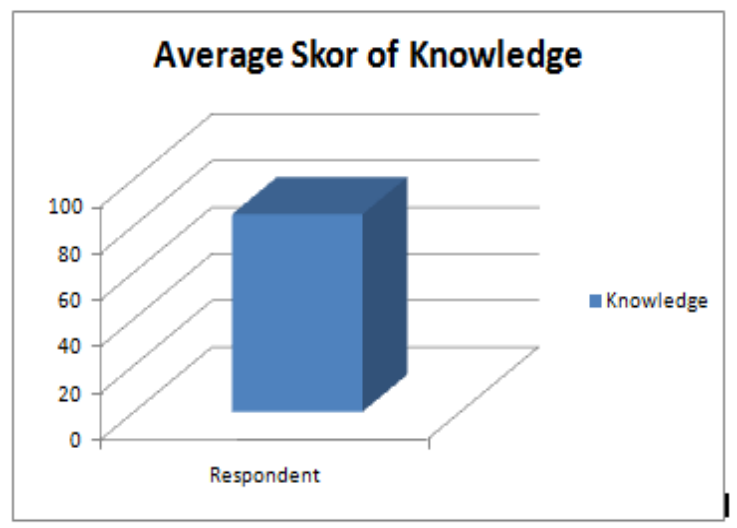

Figure 4. Average Knowledge Score Based on the Industrial Rating

\section{Work Skills}

Work skills are the ability of a person in completing the work of wide scope, choose the appropriate method of various options that have been or have not been raw by analyzing the data, and able to demonstrate performance with quality and quantity measured. The ability of the work field can be identified through work preparation indicators, work processes, outcomes and presentation, time in completing the job, managerial skills in the completion of tasks and the use of IT. The following is an industry assessment of aspects of students' work skills.

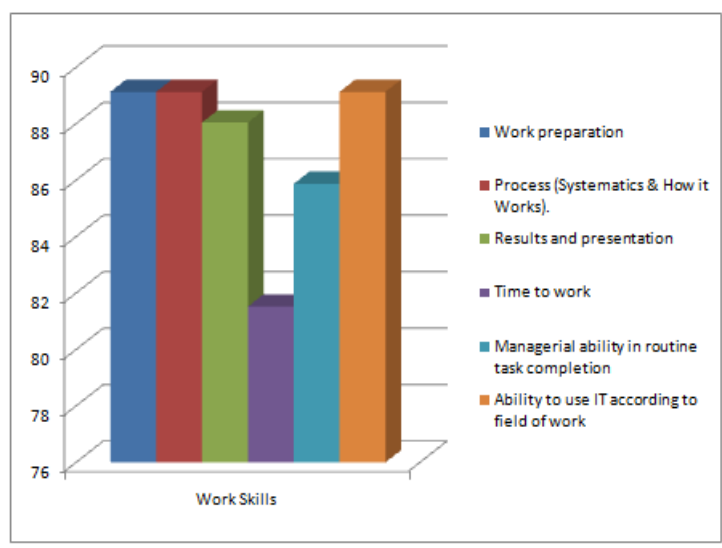

Figure 5. Values of Working Capability by Industrial Assessment

From the instrument given to 23 industry respondents to the knowledge aspect, the score for the work preparation indicator is 89.1 , the work process indicator is 89.1 , the indicator of the result and the presentation is 88,0 , the time indicator in completing the job/task is 81,5 , job completion indicator 85.8 and IT usage indicator 89.1. The overall average value of the aspects of the ability of the work field obtained value 87.1 with very high interpretation. The overall average score on the following aspects of employment capability.

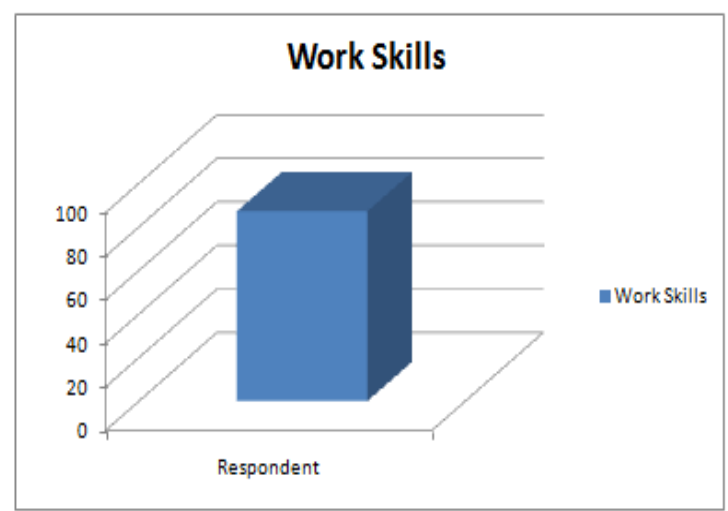

Figure 6. Average Score of Working Capability Based on the Industrial Rating

Overall assessment of industry average to technical skills of students amounted to 75.9 with very high interpretation.

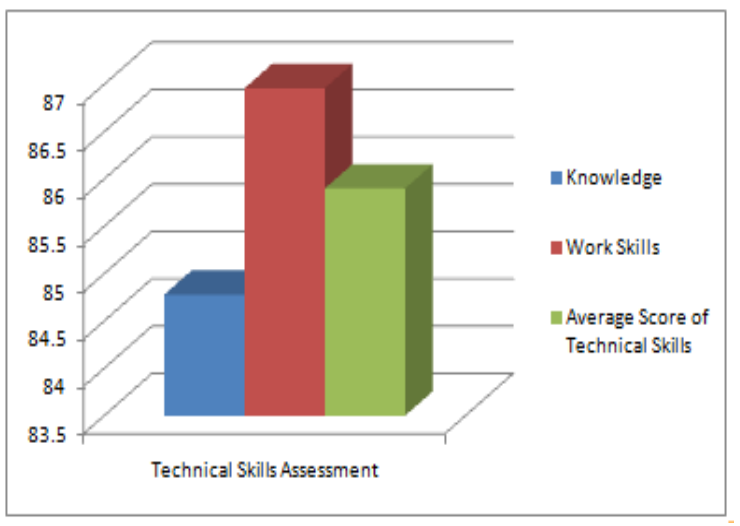

Figure 7. Industrial Assessment of Technical Skills Students

\section{Description of Industrial Data on Employability Skills Students}

Values obtained from the assessment of student employability skills instrument consisting of 2 indicators of managerial ability and attitude can be seen in the description below: 


\section{Managerial Skills}

Managerial skills are the ability of a person to manage a working group and prepare a comprehensive written report. Managerial capabilities can be identified through productivity indicators, cooperation, morale, creativity, and problem- solving. Here is an industry assessment of aspects of students' work skills:

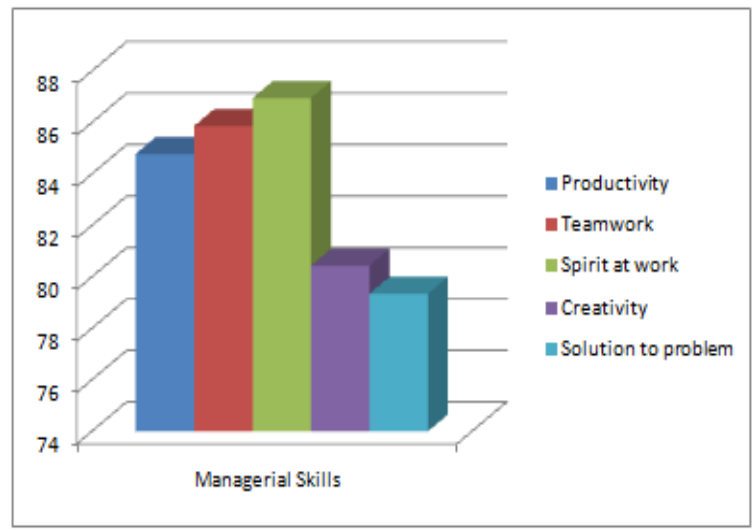

Figure 8. Values of Managerial Skills Based on the Industrial Rating

From the instrument given to 23 industry respondents on managerial aspect, the score for productivity indicator is 84,7 , cooperation indicator equal to 85,8 , job morale equal to 86,9 , creativity indicator 80,4 and problem-solving indicator 79,3. The overall average value of the aspect of managerial ability obtained 83.4 values with very high interpretation. The overall average score on the following aspects of employment capability:

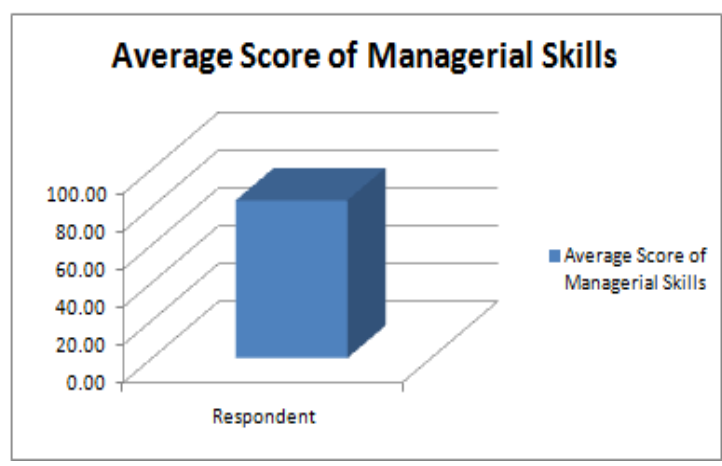

Figure 9. The Average Managerial Capability Based on the Industrial Rating

\section{Attitude}

Attitude is the personality of a person in responsible on the job itself and can be given responsibility for the achievement of group work. Attitudes can be identified through indicators of attitude in work, security and safety, honesty, discipline, leadership, and communication. Here is an industry assessment of student attitude aspects:

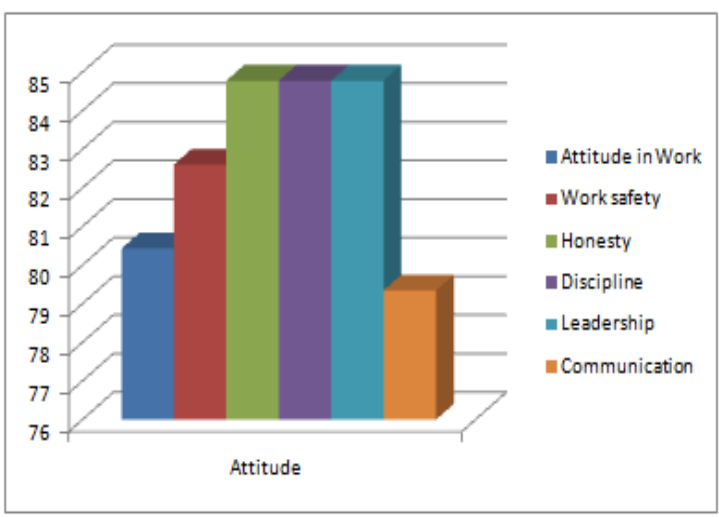

Figure 10. Value of Attitudes by Industrial Rating

From the instrument given to 23 industry respondents to the attitude aspect, the score of 80.4 for work attitude indicator, safety and safety indicator was 82.6 , the honesty indicator was 84.7, the discipline indicator was 84.7. 84.7 leadership indicators and indicators of communication ability of 79.3. The overall average score of the attitude aspect was 82.8 with a very high interpretation. The overall average value of the attitude aspect is as follows:

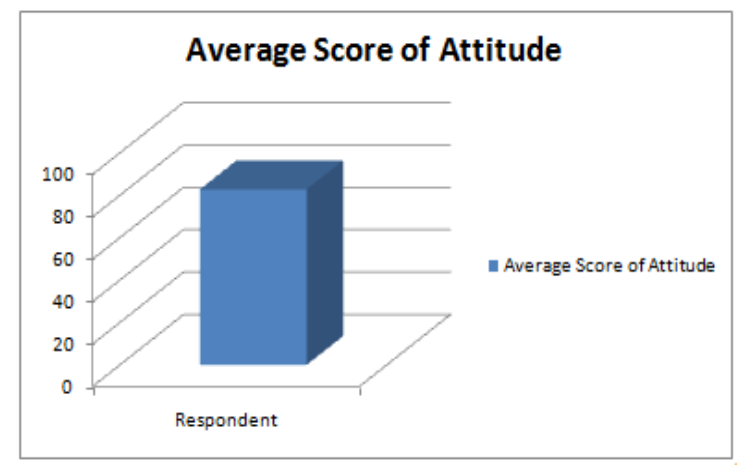

Figure 11. Average Value of Attitude based on the Industrial Rating

Overall assessment of industry average to the employability of student skill is 83,10 with very high interpretation. 


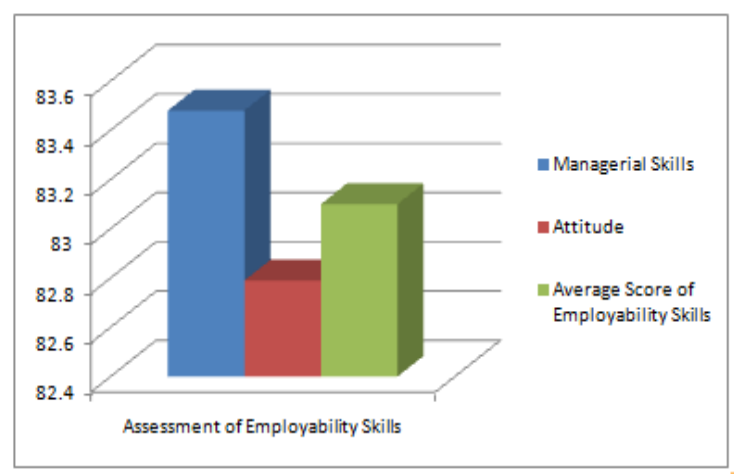

Figure 12. Industry Assessment of Employability Skills Students

\section{CONCLUSIONS}

The results show that the assessment indicators on technical aspects and employability skills are indicators received by the industry. Indicators on the technical skills aspect can be identified through the knowledge and skills of the work field. Aspects of employability skills can be identified through indicators of managerial ability and personality/personality. So that all the indicators on technical and employability skills already represent the competence level of qualification in KKNI

The overall average value of the working knowledge aspect was 84.78 with a very high interpretation. The overall average value of the aspects of the ability of the work field obtained value 87.1 with very high interpretation. Assessment of technical skills that include knowledge and ability in the field of work get an average score of 85.9 with a very high interpretation.

The overall average value of the aspect of managerial ability obtained 83.4 values with very high interpretation. The overall average score of the attitudes obtained was 82.8 with a very high interpretation. Assessment of employability skills that include managerial ability attitude gets an average score of 83.1 with very high interpretation.

\section{REFERENCES}

Anonymous. (n.d.). Technical job skills. INVESTOPEDIA. Retrieved from https://www.investopedia.com/terms/r/re sume.asp

Azwar, S. (2011). Reliabilitas dan validitas (3rd ed.). Yogyakarta: Pustaka Pelajar.
Departement of Education Science and Training. (2002). Employability skills for the future. Australia: Commonwealth.

Fraenkel, J., \& Wallen, N. E. (1990). How to design and evaluate research in education. New York: Mc. Graw Hill Pub Co.

Handayani, S., \& Wening, S. (2016). Kajian perolehan kompetensi keahlian busana butik siswa SMK: studi kasus prakerin di industri pasangan. Jurnal Pendidikan Vokasi, 6(1), 66. https://doi.org/10.21831/jpv.v6i1.8116

Indriaturrahmi, I., \& Sudiyatno, S. (2016). Peran dunia usaha dan dunia industri dalam penyelenggaraan SMK berbasis kearifan lokal di Kota Mataram. Jurnal Pendidikan Vokasi, 6(2), 162. https://doi.org/10.21831/jpv.v6i2.6277

Learning and Skills Improvement Service. (2010). Pre-redundancy employability toolkit. Retrieved from http://www.moveon.org.uk/downloadsFile/downloads315 7/23_LSIS_RedunHbook.pdf.

LOMA's Competency Dictionary. (2006). LOMA,s Competency Dictionary. In M. A. Hitt, R. E. Freeman, \& J. S. Harrison (Eds.), The Blackwell Handbook of Strategic Management. Print Publication.

Menteri Pendidikan dan Kebudayaan Republik Indonesia. Peraturan Menteri Pendidikan dan Kebudayaan Republik Indonesia Nomor 73 Tahun 2013 tentang Penerapan Kerangka Kualifikasi Nasional Indonesia Bidang Pendidikan Tinggi (2013).

Morley, R. (2010). Workplace learning guide 2010 learning for life in the 21st century. (e-book). Retrieved from https://www.gpaea.org/media/cms/Work place_Learning_Guide_B7D5A66BDA D12.pdf

Presiden Republik Indonesia. Peraturan Presiden Republik Indonesia Nomor 8 Tahun 2012 tentang Kerangka Kualifikasi Nasional Indonesia (2012).

Ridwan. (2007). Skala pengukuran variabelvariabel penelitian. Bandung: Alfabeta. 
Samani, M. (2004). Pendidikan kecakapan hidup: upaya merekonstruksi pendidikan. In seminar dan lokakarya bidang peningkatan relevansi program DUE-LIKE Jurusan Pendidikan Fisika IKIP Negeri Singaraja. Singaraja: IKIP Negeri Singaraja.

Wagiran, W. (2008). The importance of developing soft skills in preparing vocational high school graduates. (online). Retrieved August 19, 2011, from http://www.voctech.bn

Yorke, M., \& Knight, P. T. (2006). Embedding employability into the curriculum. Learning and employability series one. New York: Higher Education Academy. 